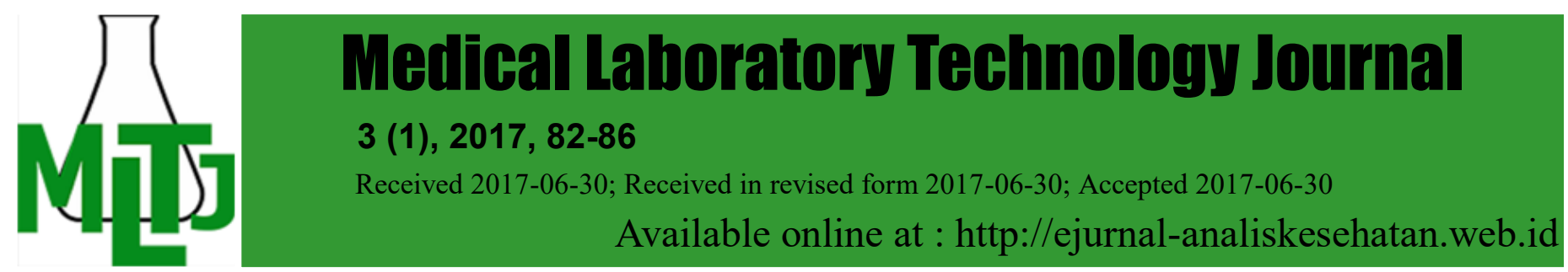

\title{
ANGKA KUMAN PADA BEBERAPA METODE PENCUCIAN PERALATAN MAKAN
}

\author{
Brilian Rizky Ananda, Laily Khairiyati \\ Program Studi Kesehatan Masyarakat Fakultas Kedokteran Universitas Lambung Mangkurat \\ JI. A. Yani KM. 36 Banjarbaru, Kalimantan Selatan, Indonesia \\ e-mail: brilianrizkyananda@gmail.com
}

\begin{abstract}
One of the food hygiene and sanitation efforts that must be implemented by the Nutrition Installation is to maintain the hygiene quality of tableware consider the equipment as a source of food contaminants. The purpose of this research was to know the effectiveness of washing the tableware method to decrease the bacterial number. The research method uses true experimental design. The research design used was posttest only control group design and sampling technique was simple random. Instruments in the research is a set of tools for experiment, sampling, and examination. The independent variable in this research is washing method on the tableware using method $A, B$, and $C$ while the dependent variable is the number of a bacteria of tableware. The results showed that the number of tableware bacteria in Sambang Lihum Psychiatric Hospital exceeded of the standard/not qualified, except on washing method $A$ which fulfilled the requirement that is under 100 colony/cm2 of tool surface. The conclusion of this research is there is a significant difference to the three washing methods which is shown with the $p$-value of 0,027 . Need to do further research on the washing process by adding sterilization process
\end{abstract}

Keywords: number of bacteria; tableware

Abstrak: Salah satu upaya higiene dan sanitasi makanan yang harus dilaksanakan oleh Instalasi Gizi yaitu menjaga kualitas kebersihan peralatan makanan mengingat peralatan sebagai sumber kontaminan makanan. Tujuan penelitian untuk mengetahui efektivitas metode pencucian peralatan makan terhadap penurunan angka kuman. Metode penelitian menggunakan desain true eksperimental. Rancangan penelitian yang digunakan adalah posttest only control group desain dan teknik pengambilan sampel adalah acak sederhana. Instrumen dalam penelitian yaitu seperangkat alat untuk percobaan, pengambilan dan pemeriksaan sampel. Variabel bebas dalam penelitian ini adalahmetode pencucian pada peralatan makan dengan menggunakan metode $\mathrm{A}, \mathrm{B}$ dan $\mathrm{C}$ sedangkan variabel terikat adalah angka kuman peralatan makan. Hasil penelitian menunjukkan angka kuman peralatan makan di Rumah Sakit Jiwa Sambang Lihum melebihi standar/tidak memenuhi syarat (TMS) kecuali pada metode pencucian A semuanya memenuhi syarat yaitu dibawah 100 koloni/ $\mathrm{cm}^{2}$ permukaan alat. Kesimpulan dari penelitian ini adalah ada perbedaan yang signifikan terhadap ketiga metode pencucian tersebut yang ditunjukan dengan nilai $p$ value sebesar 0,027 . Perlu dilakukan penelitian lanjutan pada proses pencucian dengan menambahkan proses sterilisasi.

Kata kunci: angka kuman; peralatan makan 


\section{PENDAHULUAN}

Salah satu upaya preventif untuk mewujudkan pembangunan kesehatan adalah melalui program penyehatan makanan dan pelaksana program tersebut di rumah sakit dilakukan oleh instalasi gizi rumah sakit (Depkes RI, 2009). Salah satu upaya higiene dan sanitasi makanan yang harus dilaksanakan oleh instalasi gizi yaitu menjaga kualitas kebersihan peralatan makanan (Djarismawiati dan Bambang S, 2014 ). Hal ini penting dilakukan mengingat peralatan sebagai sumber kontaminan makanan yang menyebabkan makanan tidak aman untuk dikonsumsi.

Hasil penelitian di Instalasi Gizi RSUD dr. Doris Sylvanus Palangkaraya menunjukkan bahwa angka kuman yang terdapat pada seluruh alat makan yang diperiksa berkisar antara 800 sampai dengan 622.083 koloni/ $\mathrm{cm}^{2}$ (Pranata, 2012). Pada pengambilan sampel usap alat pada Rumah Sakit $X$ nilainya melebihi standar yaitu 504 sampai 1.952 koIoni/cm² (Sumira, 2012). Hasil penelitian pada Rumah Makan di Agrowisata Bincau Kabupaten Banjar menunjukkan bahwa angka kuman yang terdapat pada seluruh alat makan yang diperiksa berkisar antara 110 sampai dengan $6700 \mathrm{koloni} / \mathrm{cm}^{2}$ (Istiqlaliah, 2009).

Tingginya angka kuman dikarenakan tahapan proses pencucian yang tidak sempurna, tempat penyimpanan peralatan yang tidak terlindung/tertutup. Penggunaan bahan pencuci yang tidak sama dan perbedaan tahapan proses pencucian yang digunakan oleh petugas menyebabkan angka kuman yang dihasilkan berbeda-beda.

Peranan peralatan makan dan masak dalam higiene sanitasi makanan sangat penting, untuk itu peranan pembersihan atau pencucian peralatan perlu diketahui secara mendasar. Pembersihan peralatan secara baik akan menghasilkan alat pengolahan makanan yang bersih dan sehat (Depkes RI, 2004). Praktek pencucian alat pengolah terdiri dari bak pencucian sedikitnya terdiri dari 3 bak pencucian yaitu mengguyur, menyabun dan membilas. Air yang digunakan untuk mencuci peralatan, apabila sudah terlihat kotor harus segera diganti dengan air yang baru, karena jika airnya tidak diganti dapat menyebabkan peralatan terkontaminasi bakteri dari air pencucian yang kotor dan pembersihan peralatan yang kurang baik (Kepmen RI, 2003).

Tahapan proses pencucian yang dilakukan petugas Instalasi Gizi Rumah Sakit
Jiwa Sambang Lihum dimulai dengan mengumpulkan sisa makanan di dalam baskom. Tiap peralatan yang kotor dicelupkan kedalam bak air sabun kemudian dibilas pada bak air pembilas (1 buah bak).

Berdasarkan hasil penelitian di Instalasi Gizi Rumah Sakit Jiwa Sambang Lihum menunjukkan bahwa pembersihan peralatan makan seperti rantang sekat menunjukkan angka kuman melebihi standar yaitu sebesar 3.175.000 koloni $/ \mathrm{cm}^{2}$ (Ananda, 2013). Jumlah tersebut diduga proses pencucian yang belum sesuai dengan standar Depkes RI 2004, sehingga angka kuman melebihi standar yang ditentukan oleh Permenkes RI No.1204/ Menkes/SK/X/2004 yaitu $100 \mathrm{koloni} / \mathrm{cm}^{2}$.

Umumnya ada beberapa cara pencucian yang sering digunakan yaitu detergen dan air pembilas menggunakan air mengalir, menggunakan detergen dan air pembilas yang ditampung dalam 2 buah bak dan ada pula yang menggunakan 3 buah bak. Berdasarkan hal tersebut, maka penulis tertarik untuk melihat efektivitas metode pencucian terhadap penurunan angka kuman peralatan makan di Rumah Sakit Jiwa Sambang Lihum.

Penelitian ini bertujuan untuk mengetahui efektivitas metode pencucian peralatan makan terhadap penurunan angka kuman di Rumah Sakit Jiwa Sambang Lihum.

\section{BAHAN DAN METODE}

Penelitian ini menggunakan desain true eksperimental untuk melihat efektivitas metode pencucian peralatan makan terhadap penurunan angka kuman. Rancangan penelitian yang digunakan adalah posttest only control group desain.

Variabel bebas dalam penelitian ini adalah metode pencucian pada peralatan makan dengan menggunakan metode $A$ (pencucian dengan sabun dan air mengalir) $B$ (pencucian dengan sabun dan air bak 2 buah) dan $C$ (pencucian dengan sabun dan air bak 3 buah) sedangkan variabel terikat adalah angka kuman peralatan makan.

Analisis data menggunakan uji KruskalWallis dengan tingkat kepercayaan 95\% $(\alpha=0,05)$.

\section{HASIL DAN PEMBAHASAN}

Berdasarkan penelitian tersebut, maka dapat di uraikan hasil pemeriksaan laboratorium dengan parameter angka kuman (TPC) sebagai berikut: 
Tabel 1. Angka Kuman Peralatan Makan TPC di BLUD Rumah Sakit Jiwa Sambang Lihum Provinsi Kalimantan Selatan Tahun 2013

\begin{tabular}{|c|c|c|c|c|c|}
\hline No & $\mathrm{s}$ & $\mathbf{P}$ & $\begin{array}{c}\text { Hasil Uji } \\
\text { (Koloni/cm² } \\
\text { permukaan alat) }\end{array}$ & $\begin{array}{c}\text { Batas Maksimum } \\
\text { (Koloni/cm² } \\
\text { permukaan alat) }\end{array}$ & Ket \\
\hline \multirow{3}{*}{1} & \multirow{3}{*}{$\mathrm{K}$} & 1 & 291.805 & 100 & TMS \\
\hline & & II & 326.459 & 100 & TMS \\
\hline & & III & 276.175 & 100 & TMS \\
\hline \multirow{3}{*}{2} & \multirow{3}{*}{ A } & 1 & 84 & 100 & MS \\
\hline & & II & 92 & 100 & MS \\
\hline & & III & 76 & 100 & MS \\
\hline \multirow{3}{*}{3} & \multirow{3}{*}{$B$} & $\mathrm{I}$ & 146 & 100 & TMS \\
\hline & & II & 178 & 100 & TMS \\
\hline & & III & 163 & 100 & TMS \\
\hline \multirow{3}{*}{4} & \multirow{3}{*}{$\mathrm{C}$} & 1 & 112 & 100 & TMS \\
\hline & & II & 107 & 100 & TMS \\
\hline & & III & 103 & 100 & TMS \\
\hline
\end{tabular}

Keterangan:

$S$ : Sampel

$\mathrm{P}$ : Pengulangan

$\mathrm{K}$ : Kontrol

A : Metode Pencucian A

B : Metode Pencucian B

C : Metode Pencucian C

Berdasarkan hasil pemeriksaan angka kuman peralatan makan di BLUD Rumah Sakit Jiwa Sambang Lihum Provinsi Kalimantan Selatan melebihi standar/tidak memenuhi syarat (TMS) kecuali pada metode pencucian A semuanya memenuhi syarat yaitu dibawah $100 \mathrm{koloni} / \mathrm{cm}^{2}$ permukaan alat.

Hasil pemeriksaan angka kuman pada peralatan makan di BLUD Rumah Sakit Jiwa Sambang Lihum Provinsi Kalimantan Selatan pada percobaan menggunakan metode $A$ didapat hasil pemeriksaan semuanya memenuhi syarat, hal ini dikarenakan air yang digunakan yaitu air kran yang mengalir sehingga air tidak digunakan berulang-ulang .

Tabel 2. Efektifivitas Metode Pencucian A terhadap Penurunan Angka Kuman

\begin{tabular}{ccccc}
\hline \multirow{2}{*}{ Ulang } & $\begin{array}{c}\text { Angka } \\
\text { Kuman } \\
\text { Kontrol }\end{array}$ & \multicolumn{3}{c}{ Metode pencucian A } \\
\cline { 3 - 5 } & Hasil & Penurunan & $\%$ \\
\hline I & 291.805 & 84 & 291.721 & 99,971 \\
II & 326.459 & 92 & 326.367 & 99,972 \\
III & 276.175 & 76 & 276.099 & 99,972 \\
\hline $\begin{array}{c}\text { Rata- } \\
\text { rata }\end{array}$ & 298.146 & 84 & 298.062 & 99,972 \\
\hline
\end{tabular}

Pada proses pencucian peralatan makan penggunaan air harus banyak, mengalir dan selalu diganti. Setiap peralatan yang dibersihkan dibilas dengan cara menggosokgosok dengan tangan atau tempat bersih sampai terasa kesat (tidak licin), bilamana masih terasa sisa-sisa lemak atau detergen dan kemungkinan masih mengandung bau amis (anyir). Pada percobaan ini digunakan air mengalir dan tahapan proses pencucian sudah sesuai prosedur sehingga angka kuman yang dihasilkan memenuhi syarat (Sekarwati, 2013).

Pada percobaan menggunakan metode $B$ hasil pemeriksaan semuanya tidak memenuhi syarat dikarenakan air yang digunakan ditampung dalam bak sehingga air tidak selalu terganti .

Tabel 3. Efektifivitas Metode Pencucian B terhadap Penurunan Angka Kuman

\begin{tabular}{ccccc}
\hline \multirow{2}{*}{ Ulang } & $\begin{array}{c}\text { Angka } \\
\text { Kuman } \\
\text { Kontrol }\end{array}$ & \multicolumn{3}{c}{ Metode pencucian B } \\
\cline { 3 - 5 } & Hasil & Penurunan & $\%$ \\
\hline I & 291.805 & 146 & 291.659 & 99,950 \\
II & 326.459 & 178 & 326.281 & 99,945 \\
III & 276.175 & 163 & 276.012 & 99,941 \\
\hline $\begin{array}{c}\text { Rata- } \\
\text { rata }\end{array}$ & 298.146 & 162 & 297.984 & 99,945 \\
\hline
\end{tabular}

Berdasarkan penelitian pada peralatan makan Pecel Lele di Tambakbayan Babarsari Sleman menunjukan bahwa angka kuman yang dihasilkan yaitu $2.973 \mathrm{koloni} / \mathrm{cm}^{2}$ permukaan alat, hal ini disebabkan pada teknik pencucian alat makan dibersihkan dahulu dari sisa makanan kemudian diguyur sehingga seluruh permukaan peralatan sempurna, setelah itu dilakukan pencucian dengan menggunakan sabun dan membilas dengan air sambil digosok dengan tangan sehingga tidak terasa sabun lagi. Pada pencucian ini tidak menggunakan air yang mengalir, hanya menggunakan dua bak kecil. Hal ini dikarenakan tidak tersedia sumber air secara langsung dan air diambil dari sumber air yang jauh dari tempat berjualan sehingga mereka lebih mengefisiensikan penggunaaan air bersih (Pohan, 2009).

Dalam buku studi sanitasi makanan dan minuman, bahwa keberadaan bak pembilas adalah sangat penting dalam proses pencucian peralatan makan. Air yang digunakan berulang-ulang untuk proses pencucian peralatan makanan akan sangat mudah terkontaminasi bakteri yang menempel pada peralatan yang akan dicuci. Kondisi seperti ini tidak memenuhi syarat higiene sanitasi bahwa peralatan hendaknya langsung dicuci dibawah kran dengan air mengalir untuk menghindarkan adanya bakteri pada air yang digunakan tersebut (Melawati dkk, 2010). 
Tabel 4. Efektifivitas Metode Pencucian C terhadap Penurunan Angka Kuman

\begin{tabular}{ccccc}
\hline \multirow{2}{*}{ Ulang } & $\begin{array}{c}\text { Angka } \\
\text { Kuman }\end{array}$ & \multicolumn{3}{c}{ Metode pencucian C } \\
\cline { 3 - 5 } & Kontrol & Hasil & Penurunan & $\%$ \\
\hline I & 291.805 & 112 & 291.693 & 99,962 \\
II & 326.459 & 107 & 326.352 & 99,967 \\
III & 276.175 & 103 & 276.072 & 99,963 \\
\hline $\begin{array}{l}\text { Rata- } \\
\text { rata }\end{array}$ & 298.146 & 107 & 298.039 & 99,964 \\
\hline
\end{tabular}

Bak pencuci berhubungan dengan kontaminasi silang antara peralatan dan bak pencucian yang tidak bersih. Bak pencuci setidaknya terdiri dari tiga bilik, yaitu bak ke-I dan II merupakan bak pembilas dan pada bak ke-III disebut bak pembilas terakhir (final rance atau disebut desinfection). Di dalam bak ketiga ini piring dan gelas untuk terakhir kalinya dibilas terutama kemungkinan masih menempel lemak pada piring atau gelas dengan air panas dengan suhu $82^{\circ} \mathrm{C}$. Pada metode pencucian ini, bak ke-III tidak diberi air panas, hal ini dikarenakan peralatan yang ada di BLUD Rumah Sakit Jiwa Sambang Lihum masih belum menyediakan untuk proses sanitizing/ disinfection sehingga menyebabkan angka kuman yang terdapat pada peralatan makan masih melebihi standar yang ditentukan.

Tingginya angka kuman dapat mengkontaminasi makanan yang disajikan pada peralatan tersebut, mengingat peralatan sebagai sumber kontaminan makanan yang menyebabkan makanan tidak aman untuk dikonsumsi. Angka kuman tertinggi terdapat pada peralatan yang dicuci menggunakan metode $B$, hal ini terjadi karena pada proses pencucian hanya dilakukan pembilasan sebanyak 2 kali sehingga peralatan masih terdapat sisa detergen dan berminyak. Sedangkan angka kuman terendah terdapat pada peralatan yang dicuci menggunakan metode $A$, hal ini dikarenakan proses pencucian yang dilakukan dengan menggunakan air mengalir.

Berdasarkan hasil pengamatan yang dilakukan, tingginya angka kuman peralatan disebabkan oleh faktor proses pencucian. Proses pencucian yang tidak sempurna menjadi salah satu penyebab tingginya angka kuman peralatan makan. Proses pencucian yang dilakukan dalam percobaan ini sudah mengikuti prosedur yang sebenarnya.

Pada tahapan akhir dari proses pencucian adalah melaksanakan proses sanitizing/ disinfection, hal ini dikarenakan proses terse- but sangat penting dalam menentukan kualitas bakteriologis peralatan makan. Dalam penelitian ini tidak melakukan tahapan ini, sehingga menyebabkan angka kuman yang terdapat pada peralatan makan masih melebihi standar yang ditentukan. Hal ini dikarenakan peralatan yang ada di BLUD Rumah Sakit Jiwa Sambang Lihum masih belum menyediakan untuk proses sanitizing /disinfection sehingga tidak dilakukan desinfeksi.

Berdasarkan hasil uji kruskal-wallis dengan derajat kepercayaan 95\% didapat Asymp. Sig sebesar 0,027 (Asymp. Sig < $0,05)$ yang berarti angka kuman ketiga metode pencucian berbeda signifikan. Hasil penelitian ini menunjukkan bahwa angka kuman yang dihasilkan tiap-tiap metode berbeda, sehingga hal ini membuat ada perbedaan yang signifikan terhadap ketiga metode pencucian tersebut yang ditunjukan dengan nilai Asymp. Sig sebesar 0,027.

Hasil penelitian ini sejalan dengan hasil penelitian yang dilakukan oleh Suryani bahwa ada hubungan antara metode pencucian terhadap angka kuman peralatan makan dengan nilai $p=0,037$. Nilai Rasio Prevalensi $(R P)=$ 1,651 yang menunjukkan bahwa pencucian alat makan yang tidak baik akan mempengaruhi jumlah angka kuman di peralatan makan sebesar 1,651 kali lebih besar dibanding dengan pencucian alat makan yang baik. Kontaminasi dalam makanan dapat langsung terjadi melalui 2 cara yaitu kontaminasi langsung dan kontaminasi silang. Terjadinya kontaminasi yang berasal dari peralatan makan disebabkan penanganan peralatan makan yang tidak saniter, baik melalui proses pencucian, pengeringan maupun pada penyimpanan (Suryani, 2014).

Kegiatan pencucian akan lebih maksimal dalam penurunan angka kuman jika dilakukan dengan kegiatan sanitizing/ desinfection. Hal ini sejalan dengan penelitian Trisnawati yang menyatakan bahwa perendaman air panas terhadap peralatan penyajian memberikan pengaruh yang signifikan terhadap angka kuman dengan $p=0,00$ (Trisnawati, 2009). Andriyani juga menyatakan, berdasarkan hasil uji statistic dengan uji-t menunjukkan $p=0,0019$ yang berarti signifikan bahwa ada pengaruh larutan detergent dan larutan klorin terhadap penurunan jumlah angka kuman alat makan. Hal ini berarti jumlah angka kuman yang ada pada alat makan akan turun setelah dilakukan pencucian dengan metode three compartement sink dengan menggunakan larutan detergen dan larutan klorin (Andriyani, 2009). 


\section{KESIMPULAN}

Angka kuman peralatan makan di BLUD Rumah Sakit Jiwa Sambang Lihum Provinsi Kalimantan Selatan melebihi standar/tidak memenuhi syarat (TMS) kecuali pada metode pencucian A semuanya memenuhi syarat yaitu dibawah $100 \mathrm{koloni} / \mathrm{cm}^{2}$ permukaan alat.

Angka kuman pada peralatan makan pada percobaan menggunakan metode $A$ didapat hasil pemeriksaan semuanya memenuhi syarat, hal ini dikarenakan air yang digunakan yaitu air kran yang mengalir sehingga air tidak digunakan berulang-ulang.

Pada percobaan menggunakan metode $B$ hasil pemeriksaan semuanya tidak memenuhi syarat dikarenakan air yang digunakan ditampung dalam bak sehingga air tidak selalu terganti.

Pada percobaan menggunakan metode $\mathrm{C}$ hasil pemeriksaan semuanya tidak memenuhi syarat dikarenakan air yang digunakan ditampung dalam bak sehingga air tidak selalu terganti. Tetapi angka kuman yang dihasilkan masih rendah dibandingkan angka kuman yang menggunakan metode $B$.

Hasil penelitian ini menunjukkan bahwa angka kuman yang dihasilkan tiap-tiap metode berbeda, sehingga hal ini membuat ada perbedaan yang signifikan terhadap ketiga metode pencucian tersebut yang ditunjukan dengan nilai Asymp. Sig sebesar 0,027 .

\section{SARAN}

Perlu dilakukan penelitian lanjutan dengan menambahkan pemeriksaan bakteriologis air agar mengetahui pengaruh kualitas air terhadap angka kuman peralatan.

Perlu dilakukan penelitian lanjutan pada proses pencucian dengan menambahkan proses sterilisasi.

Perlu dilakukan penelitian lanjutan dengan mengatur jumlah peralatan yang dicuci dengan metode pencucian menggunakan 3 buah bak, sehingga dapat diketahui pada jumlah peralatan keberapa angka kuman melebihi standar yang ditetapkan

\section{DAFTAR PUSTAKA}

Ananda, B. (2013). Kualitas Bakteriologis Peralatan Makan di BLUD Rumah Sakit Jiwa Sambang Lihum Provinsi Kalimantan Selatan. Poltekkes Kemenkes Banjarmasin.

Andriyani, A. (2009). Pengaruh larutan detergent dan larutan klorin pada proses pencucian alat makan dengan metode three compartement sink terhadap penurunan jumlah angka kuman pada alat makan di RS PKU Muhammadiyah Surakarta. Jurnal GASTER, 5(1), 379387.

Departemen Kesehatan Republik Indonesia. (2004). Kumpulan Modul Kursus Hygiene Sanitasi Makanan Dan Minuman. Jakarta: Dirjen PPM \& PL.

Depkes RI. (2009). Undang-Undang RI. Nomor 36 Tahun 2009 tentang Kesehatan. Jakarta.

Djarismawati, \& Bambang, S. (2004). Pengetahuan dan perilaku penjamah tentang sanitasi pengolahan makanan pada instalasi gizi rumah sakit di Jakarta. Media Litbang Kesehatan. Jakarta.

Istiqlaliah, A. (2009). Kualitas Kebersihan Peralatan Makan Pada Rumah Makan di Agrowisata Bincau Kabupaten Banjar. Poltekkes Kemenkes Banjarmasin.

Kemenkes RI. (2003). Keputusan Menteri Kesehatan Republik Indonesia. Nomor1098/Menkes/SKNII/ 2003 tentang Hygiene dan Sanitasi Jasaboga. Jakarta.

Melawati. (2010). Survey Kontaminasi Bakteri Patogen Pada Makanan Dan Minuman Yang Dijual Di Sekitar Gedung Perkantoran di Jakarta. Jakarta.

Pohan. (2009). Pemeriksaan Escherichia coli pada Usapan Peralatan Makan Yang Digunakan Oleh Pedagang Makanan Di Pasar Petisah Medan.

Pranata, H. (2012). Penerapan Higiene Sanitasi Pengelolaan Makanan di Instalasi Gizi Rumah Sakit Umum Daerah Dr. Doris Sylvanus Palangkaraya Kalimantan Tengah. Poltekkes Kemenkes Banjarmasin.

Sekarwati, N. (2013). Hubungan sanitasi alat makan "piring" dengan angka kuman pada peralatan makan pecel lele di Tambakbayan Babarsari Sleman. Jurnal Kesehatan Masyarakat, 6(2).

Sumira, I. (2012). Gambaran Hygiene Sanitasi Dan Pemeriksaan Bakteriologis Pada Peralatan Makan di Instalasi Gizi RS $X$. Universitas Riau.

Suryani, D. (2014). Keberadaan angka kuman ikan bawal bakar dengan peralatan makan bakar. Jurnal Kesehatan Masyarakat, 9(2).

Trisnawati, I. (2010). Pengaruh Perlakuan Sanitizer Air Panas Pada Peralatan Penyajian Terhadap Penurunan Angka Total Bakteri dan coliform di Bangsal Geriatri RSUP dr. Kariadi Semarang. Universitas Diponegoro. 